\title{
EVA Film Reinforced with Acid Functionalized Graphene Nanoplatelets as a Transparent Barrier Layer to Enhance the Durability of Solar Cells
}

\author{
K. Yuwawech ${ }^{1,2}$ and J. Wootthikanokkhan ${ }^{1,2, *}$ \\ ${ }^{1}$ Division of Materials Technology, School of Energy, Environment and Materials, \\ King Mongkut's University of Technology Thonburi (KMUTT), \\ Bangkok 1014, Thailand \\ ${ }^{2}$ Nanotec-KMUTT Center of Excellence on Hybrid Nanomaterials for Alternative \\ Energy, King Mongkut's University of Technology (KMUTT), Thonburi, \\ Bangkok 10140, Thailand \\ Tel: +662-4708692; Fax: +662-4708643 \\ "Email jatuphorn.woo@kmutt.ac.th
}

\begin{abstract}
This research work concerns the development of transparent barrier films based on ethylene vinyl acetate copolymer (EVA) reinforced with the acid functionalized graphene nanoplatelets (GNP). GNP was melt-compounded with EVA in a micro-compounder via two types of mixing schemes. The effect of concentration of GNP on the barrier, thermomechanical and optical properties of the EVA composite films were investigated. Water vapour transmission rate of the EVA film decreased by more than $70 \%$ after $0.001-0.01$ wt $\%$ of the GNP was applied. The visible light transmittance in the range of $84-91 \%$ was maintained. SEM images showed a random distribution of GNP in the EVA matrix with intimate contact between phases. FTIR spectra imply a polar-polar interaction between the two materials. Tensile toughness of the composite films increased with the concentration of GNP. These demonstrated that the acid functionalized GNP is compatible with EVA. The degree of swelling of the cured EVA films also decreased with the GNP content. The above effects were less obvious when the mixing scheme was changed to the master-batch method. Finally, by applying the EVA/GNP film to encapsulate dye-sensitised solar cells, the lifetime of the device was prolonged by at least three weeks, with the normalised PCE value of 0.74 .
\end{abstract}

Keywords: Solar cells; encapsulants; graphene; EVA.

\section{INTRODUCTION}

The development of high-performance barrier coating has been an interesting subject. This was motivated by the attempts to increase the lifetime of many products such as advanced electronic devices, organic light emitting diodes [1], new generation solar cells (organic photovoltaic, dye sensitised solar cells, perovskite solar cells) [2], and food packaging applications [3]. This is because materials underneath the products are usually sensitive to moisture and oxygen, which can induce some degradation. Depending on the applications, the required water vapour transmission rate (WVTR) and oxygen transmission rate (OTR) for each product are versatile. For example, the ideal WVTR and OTR values for organic light emitting diodes and organic photovoltaic cells $<10^{-6}$ $\left(\mathrm{g} / \mathrm{m}^{2} /\right.$ day) and $<10^{-5}\left(\mathrm{~cm}^{3} / \mathrm{m}^{2} /\right.$ day $)$, respectively [4]. The values are rather demanding and challenging. At present, there is no universal common material for encapsulation of 
the new generation solar cells. On the other hand, the ethylene-vinyl acetate copolymer (EVA) film has been widely used as an encapsulation material for the conventional solar cell modules. In this regard, it is interesting to explore the feasibility of improving barrier properties of EVA without sacrificing its thermo-mechanical and optical properties, for an encapsulation of the new generation solar cells.

Generally, to enhance barrier properties of polymers, three main strategies can be used, which are (1) by coating it with a more hydrophobic material, (2) by the development of multilayered films, utilizing a combination of organic and inorganic materials, and (3) by compounding it with nano-fillers to induce a formation of tortious pathway within the polymer matrix [5]. About this study, the last approach was interested and focused. This was because the melted compounding technique is compatible with the existing extrusion process normally used for the production of EVA films in industries [6]. In this regard, several types of nano-fillers might be used, including clay [7], metal oxides nanoparticles [8,9] nanocelluloses [10] and graphene sheets [11, 12]. Tseng et al. [13] improved the moisture barrier properties of polyimide by using graphene oxide (GO). After adding $0.001 \mathrm{wt} \%$ of GO, water vapour transmission rate (WVTR) of the polymer decreased rapidly from $181\left(\mathrm{~g} \mathrm{~m}^{-2}\right.$ day $\left.^{-1}\right)$ to $31\left(\mathrm{~g} \mathrm{~m}^{-2}\right.$ day $\left.^{-1}\right)$. It was also found that the optical transparency of the polymer film was maintained to $95 \%$ after $0.001 \mathrm{wt} \%$ of the GO was added. Recently, Mensah et al. [14] attempted to elucidate the effect of both graphene oxides (GO) and the reduced GO in the nitrile rubber (NBR) and the ethylene propylene diene copolymer (EPDM). It was found that the reduced graphene oxides are more compatible with the NBR rubber than with the less polar EPDM. This was related to the presence of hydroxyl and carboxylic groups on the surface of the graphene oxide sheet.

Rafiee et al., [15] studied the effects of graphene nanoplatelets (GNP) on mechanical properties of an epoxy resin and found that the tensile strength and modulus of the polymer increased by up to $20 \%$ after adding $0.1 \mathrm{wt} \%$ of the graphene. It was also observed that a reinforcing efficacy of the graphene platelets were superior to that of carbon nanotubes. Gaska et al. [16] studied the effect of GNPs on thermal properties of LDPE and found that the decomposition temperature of the polymer increased from 426 ${ }^{\circ} \mathrm{C}$ to the range of $435-442{ }^{\circ} \mathrm{C}$ after adding about $1-5$ wt.\% of the GNPs. Soheilmoghaddam et al. [17] prepared EVA/GNP composites via a solution-based process. After testing, it was found that the maximum tensile strength of the composite was obtained when $3 \mathrm{phr}$ of the GNPs was added. Electrical conductivity values of the EVA/GNP composites also increased by 10 order of magnitude when 2 phr of the GNPs was applied. The above effects were ascribed to good dispersion of GNPs in the EVA matrix, which led to a formation of an interconnected and continuous network throughout the composites. A capability of the GNP in acting as a barrier enhancing filler for EVA was also demonstrated. Oxygen permeability through the EVA film decreased by $31 \%$ when 3 phr of GNP was added to the polymer.

In this study, rather than utilising the pristine GNPs for mixing with EVA via the solution-based process, attempted were made to prepare the EVA/acid functionalized GNP films via a melted-compounding process, presumed that the acid functionalized GNPs are compatible with the EVA. The primary aim of the work is to investigate the effects of the mixing methods and concentration of GNPs on thermo-mechanical, morphological, optical and barrier properties of the EVA composite films. Also, feasibility of applying the developed EVA/GNP composite film to prolong the lifetime of the solar cell was also of interest. Noteworthy, in this study, rather than applying the developed composite films to encapsulate the conventional solar cell modules, we 
decided to determine an efficacy of the composite film in the dye sensitize solar cell (DSSC) system. This was because the durability of DSSC is still poor and have yet to be further improved. Until now, to the best of our knowledge, there is no commercial product available for the encapsulation of DSSC. Our earlier work [18] has shown that by coating the device with a room temperature curable polyurethane (PU) resin, the lifetime of DSSC could be prolonged for several weeks, with the normalised power conversion efficiency value close to 1 . In this study, therefore, it was believed that by further combining the EVA/GNP as a secondary barrier film to encapsulate of the device, greater durability of the device could be expected.

\section{EXPERIMENTAL}

\section{Chemicals}

EVA pellets (ESCORENE UL 04533, containing $33 \mathrm{wt} \%$ of vinyl acetate repeating units with the MFI value of $45 \mathrm{~g} / 10 \mathrm{~min}$ ) was purchased from ExxonMobil Chemical, USA. A primary antioxidant (bis (2,2,6,6-tetramethyl-4-piperidinyl) sebacate) [Tinuvin 770] and a secondary antioxidants (2,4-bis(1,1-dimethylethyl) phosphite (I) and dioctadecyl 3,3thiopropionate) [Irganox $802 \mathrm{FD}$ ] used for compounding with EVA were obtained from Ciba Specialty Co., Ltd. (Basel, Switzerland). Also, 2, 5-bis (tert-butyldioxy)-2, 5dimethylhexane (Luperox 101), used as a curing agent, was supplied by Arkema Co., Ltd. (Philadelphia, PA). The graphene nanoplatelets used in this study was an acid vapour grade (HDPlas® GNP-COOH-STD), purchased from the Haydale Technologies (Thailand) Co.Ltd. According to a technical datasheet from the supplier, the specific surface area, the planar size and the thickness values of the GNP were $20 \mathrm{~m}^{2} / \mathrm{g}, 0.3-5 \mu \mathrm{m}$ and $<50 \mathrm{~nm}$, respectively. In addition, the shape and dimensions of the GNP were verified by our SEM image in Figure 1(a).

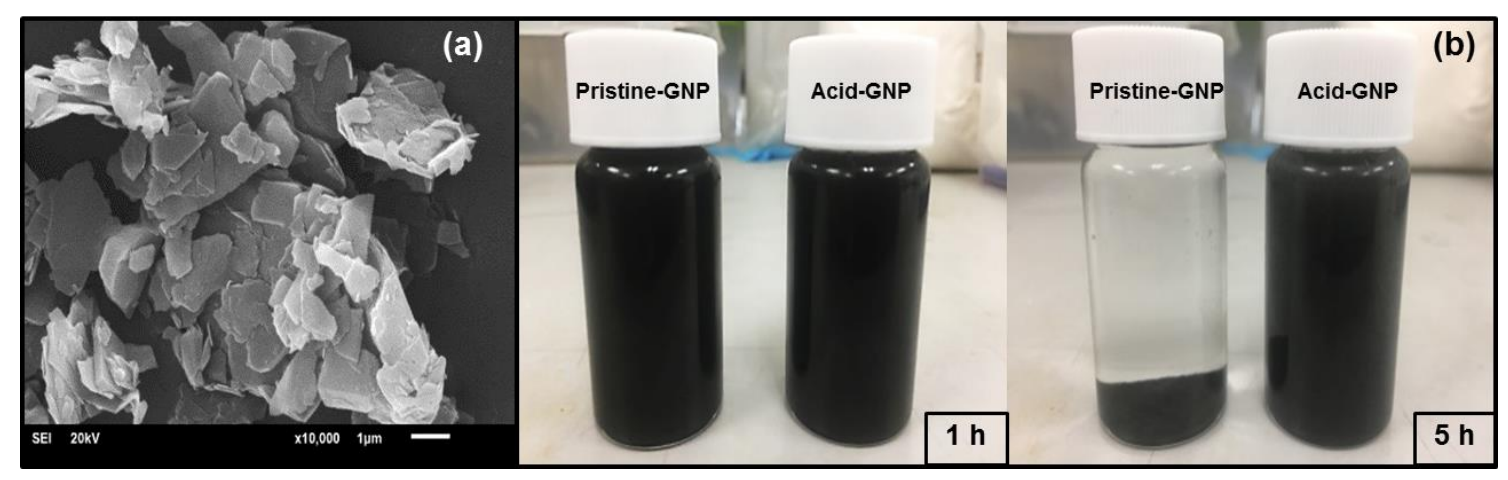

Figure 1. (a) SEM image of the acid functionalized GNP and; (b) photographs illustrating the state of dispersion of the pristine GNP and the functionalized GNP in aqueous solution $(1 \mathrm{mg} / \mathrm{ml})$ at $1 \mathrm{~h}$ and $5 \mathrm{~h}$.

The presence of acid groups on the modified GNP was confirmed by an XPS technique. The XPS peaks representing carbon $(2.87 \mathrm{eV}$, accounted for $95.33 \mathrm{wt} \%)$ and oxygen (4.67 eV, accounted for $4.67 \mathrm{wt} \%$ ) atoms in the survay spectra were noted (see the supporting information). The deconvoluted peaks from narrowed scan spectra also show the presence of $\mathrm{SP}^{2}$ hybridization and $\mathrm{C}-\mathrm{O}$ bonds. In addition, indirect evidence supporting the presence of acid groups on the surface of GNP was seen from the state of dispersion of the acid functionalized GNP in an aqueous solution (Figure 2b). This 
reflects the different polarity between the pristine and the functionalized GNP. An electrical conductivity value of the GNP, determined from the 4-points probe technique, was $2.39 \times 10^{4} \mathrm{~S} / \mathrm{cm}$. This is comparable to that was reported in the literature $[19,20]$.

\section{Compounding and Fabrication of the EVA Films}

Compounding formulas of the various EVA films are summarised in Table 1. For the first mixing scheme, $5 \mathrm{~g}$ of the EVA pellets were directly mixed with all ingredients in a microcompounder (Thermo Scientific HAAKE Mini CTW). The mixing temperature and the screw rotating speed used were $110^{\circ} \mathrm{C}$ and $40 \mathrm{rpm}$, respectively. For the second mixing scheme, a master-batch containing $1 \mathrm{~g}$ of EVA and GNP (10 wt. \%) were prepared by a solution mixing process, in chloroform $(9 \mathrm{ml})$. After drying, the casted film was cut and then mixed again with remaining EVA pellets in a micro-compounder. Finally, the extrudate was cut and fabricated into a $0.30( \pm 0.04) \mathrm{mm}$ thick, square-shaped $(20 \mathrm{~cm} \mathrm{x}$ $20 \mathrm{~cm}$ ) film, using a hydraulic compression mold (LabTech Engineering Co., Ltd.) at 160 ${ }^{\circ} \mathrm{C}$ for a given time. More details concerning the compression molding and the curing time of EVA film can be seen from our earlier report [21].

Table 1. Compounding formulas of EVA composite films.

\begin{tabular}{lccccc}
\hline $\begin{array}{l}\text { Chemicals } \\
\text { (with trade }\end{array}$ & \multicolumn{5}{c}{ Sample Codes/ Ingredient Content (phr) } \\
\cline { 2 - 6 } names) & EVA & EVA/GNP\#1 & EVA/GNP\#2 & EVA/GNP\#3 & EVA/GNP\#4 \\
\hline $\begin{array}{l}\text { EVA polymer } \\
\text { Primary }\end{array}$ & 100 & 100 & 100 & 100 & 100 \\
$\begin{array}{l}\text { antioxidant } \\
\text { Secondary }\end{array}$ & 0.1 & 0.1 & 0.1 & 0.1 & 0.1 \\
$\begin{array}{l}\text { antioxidant } \\
\text { Curing agent }\end{array}$ & 0.2 & 0.2 & 0.2 & 0.2 & 0.2 \\
GNP & 1.5 & 1.5 & 1.5 & 1.5 & 1.5 \\
\hline
\end{tabular}

\section{Characterisation and Testing}

\section{Gel content and swelling index test}

The amount of an insoluble fraction in the cured EVA films was quantified by a gel content test. The test was carried out by the ASTM D-2765 standard method, using xylene and a refluxing apparatus. In addition, the degree of crosslinking of the various EVA based films were accessed by using a swelling test. The swelling experiment was carried out for seven days. More details concerning the experimental procedures were described in our earlier report [21, 22].

\section{Mechanical properties}

The tensile properties of the various EVA films were determined by the ASTM D638 standard, using a universal testing machine (UTM, Lloyd, LR50 k). The test was carried out at a crosshead speed of $500 \mathrm{~mm} / \mathrm{min}$, using a $1 \mathrm{kN}$ load cell. At least five specimens were tested for each sample. The average values of Young's modulus, tensile strength, 
elongation at break, and tensile toughness, calculated via the use of a software (Nexygen) of the UTM, were reported.

Morphology

The morphology of the EVA/GNP composites were examined using a scanning electron microscope (FEI Nova NanoSem 450), equipped with a secondary electron detector. The sample was coated with gold prior to the SEM experiment. The accelerating voltage used was $10-30 \mathrm{kV}$.

\section{Thermal analysis}

The weight composition and thermal stability of the EVA films were determined by thermal gravimetric analysis (TGA). The TGA experiments were carried out with a NETZSCH (TGA 209-F3 model). Approximately $10 \mathrm{mg}$ of each sample was used, and the specimen was heated over temperatures ranging between $25^{\circ} \mathrm{C}$ and $800{ }^{\circ} \mathrm{C}$, at a heating rate of $20^{\circ} \mathrm{C} / \mathrm{min}$, under a nitrogen gas atmosphere. In addition, glass transition temperature $\left(\mathrm{T}_{\mathrm{g}}\right)$, melting temperature $\left(\mathrm{T}_{\mathrm{m}}\right)$ and crystallinity values of the polymer composites were analysed by using a differential scanning calorimetry (DSC) technique. Practically, about $10 \mathrm{mg}$ of the sample was used, and the DSC experiment was carried out with a NETZSCH (DSC 204-F1 model) instrument under a nitrogen gas atmosphere, and at a heating rate of $10^{\circ} \mathrm{C} / \mathrm{min}$ over temperatures ranging between $\left(-50{ }^{\circ} \mathrm{C}\right)$ and 200 ${ }^{\circ} \mathrm{C}$. The percentage of crystallinity $\left(\mathrm{X}_{\mathrm{c}}\right)$ of each sample was calculated, using the value of enthalpy of fusion of EVA crystal (293 J/g) [23] as a reference.

\section{Optical properties}

The absorption spectra of various samples were recorded on a Shimadzu UV-3100 spectrophotometer. The visible light transmittance was determined by the ASTM E903 standard method. Three measurements were made of each sample, and the averaged weight values were reported.

\section{Water absorption}

The percentage of moisture absorption of the various EVA films were determined by measuring changes in weight of the specimen $\left(2 \times 2 \mathrm{~cm}^{2}\right)$ after immersion in water, at room temperature, for $20 \mathrm{~min}$. The percentage water absorption (A \%) was then calculated by using the following equation: $\mathrm{A}(\%)=\left(\left(\mathrm{W}_{\text {wet }}-\mathrm{W}_{\mathrm{d}}\right) / \mathrm{W}_{\mathrm{d}}\right) \times 100$, where $\mathrm{W}_{\text {wet }}$ and $\mathrm{W}_{\mathrm{d}}$ are the weight of the specimen conditioned at $20 \mathrm{~min}$ and the initial weight of the dried specimen, respectively.

\section{Water vapour transmission}

The barrier property of the EVA films was determined by measuring the water vapour permeation rate (WVTR). The test was carried out by the ASTM E96-93 standard method with some modification. At least three specimens were tested for each sample. More details concerning the experimental procedure and the equation used for the calculation of WVTR value can be seen from our earlier report. [24] 


\section{Solar Cell Encapsulation and Performance Test}

The dye-sensitized solar cell (DSSC) devices with the configuration of $\mathrm{FTO} / \mathrm{TiO}_{\mathrm{x}} / \mathrm{TiO}_{2} / \mathrm{Pt} / \mathrm{FTO}$ were firstly prepared, using ruthenium-based dye (N71 from Solaronix, Switzerland) and a liquid electrolyte (HI-30, purchased from Solaronix). The active area of the DSSC was $0.4 \times 1.0 \mathrm{~cm}^{2}$. More details concerning the DSSC fabrication process can be seen from our earlier reported [18]. Next, the EVA composite film, namely EVA/GNP\#2D, was used for the encapsulation of the fabricated devices. Schematic diagram of the encapsulation process of the DSSC is illustrated in Figure 2. Finally, the performance of the DSSCs were determined by measuring J-V characteristics of the various cells, using the Keithley 2400 source meter under 1.5 AM. The light source was generated by a solar simulator (Newport $91150 \mathrm{~V}$ model, $1000 \mathrm{~W}$, Xenon lamp), equipped with a $1.5 \mathrm{G}$ air mass filter. In addition, the durability of the DSSCs were evaluated by following up changes in normalised power conversion efficiency (PCE) values of the devices as a function of time.

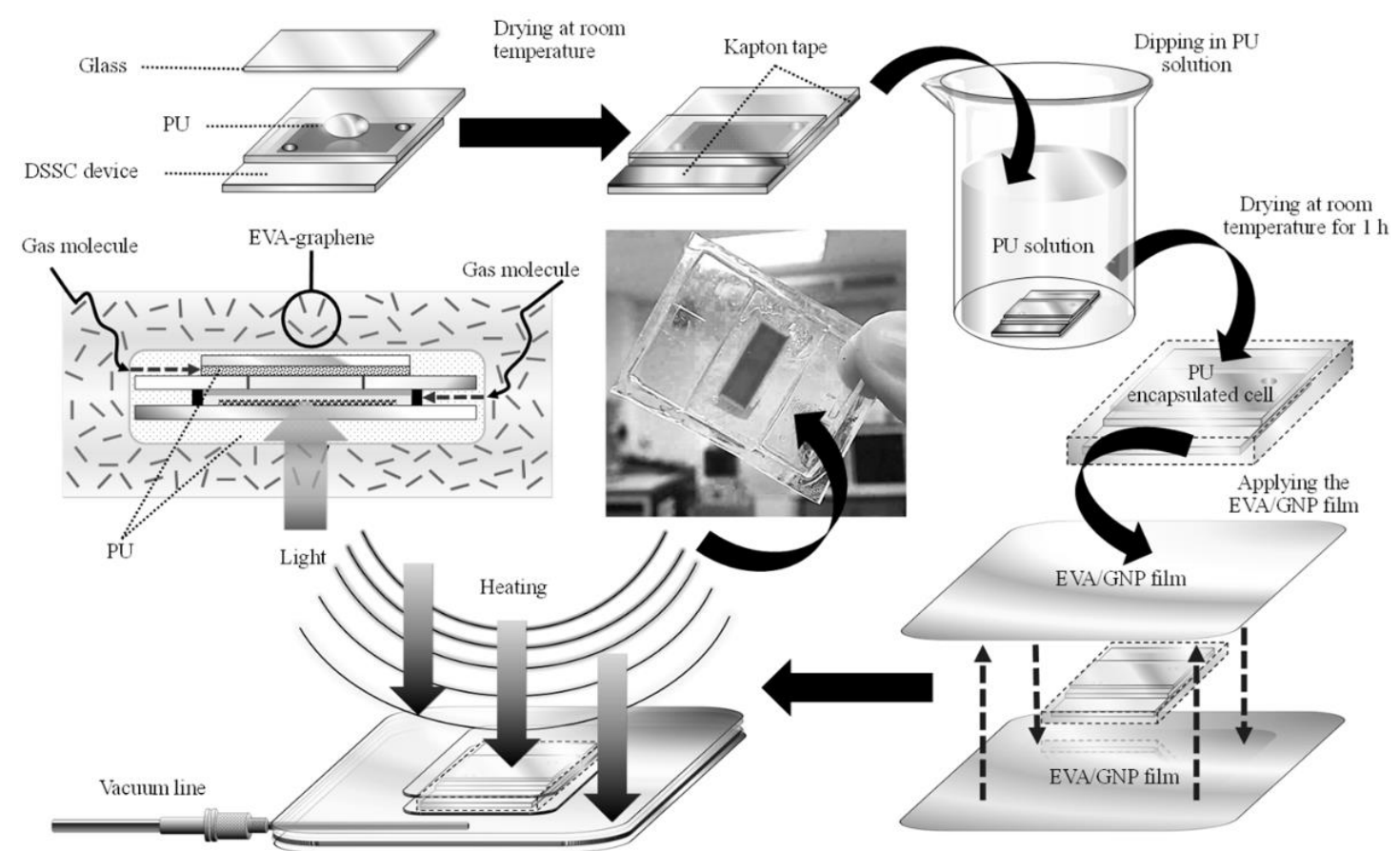

Figure 2. Schematic diagram illustrating the encapsulation steps; coating of the fabricated DSSC with PU resin followed by lamination with the EVA composite film.

\section{RESULTS AND DISCUSSION}

\section{Characterised Structures}

From the FTIR spectrum of the neat EVA film (Figure 3), the peaks at wavenumber of $1733 \mathrm{~cm}^{-1}$ (C=O ester, stretching), $1238 \mathrm{~cm}^{-1}$ (C-O-C, stretching), 1166 $\mathrm{cm}^{-1}\left(\mathrm{C}-\mathrm{O}\right.$, stretching) and $1015 \mathrm{~cm}^{-1}\left(\mathrm{C}-\mathrm{O}, \mathrm{CH}_{3}\right)$ representing the vinyl acetate repeating units [25] were observed. In addition, the peaks at $2918 \mathrm{~cm}^{-1}(\mathrm{C}-\mathrm{H}$, asymmetric stretching), $2850 \mathrm{~cm}^{-1}$ (C-H symmetric stretching), $1466 \mathrm{~cm}^{-1}(\mathrm{C}-\mathrm{H})$ and $715 \mathrm{~cm}^{-1}\left(\mathrm{CH}_{2}\right.$, rocking mode in the amorphous part) assigned to the ethylene repeating units of EVA can be seen [26]. After mixing with $1.0 \mathrm{wt} \%$ of GNP, the peak at $1166 \mathrm{~cm}^{-1}$ slightly shifted 
toward the higher wavenumber, whereas a broad peak centred around $3428 \mathrm{~cm}^{-1}$ immerged. The latter peak represents the vibration of the hydroxy group $(\mathrm{OH})$ on the surface of the GNP [27]. The above spectral changes reflect an intermolecular interaction between the functionalized GNP and the acetate groups of EVA. In addition, the XRD pattern of the neat GNP (Figure 4) shows the characteristic peaks at $2 \theta$ angle of $26.5^{\circ}$ and $54.7^{\circ}$. These correspond to the stacking of 002 and 004 crystal planes of GNP with the $d-$ spacing values of $3.35^{\circ} \mathrm{A}$ and $1.68^{\circ} \mathrm{A}$, respectively. After mixing with EVA, the XRD peak located at $26.5^{\circ}$ still exist whereas intensity of the peak at $54.7^{\circ}$ became less obvious. This was probably due to a dilution effect, taking into account the fact that a considerably low concentration of GNP was used. Nevertheless, the above patterns indicate that microstructure of the GNP did not change after mixing with EVA.

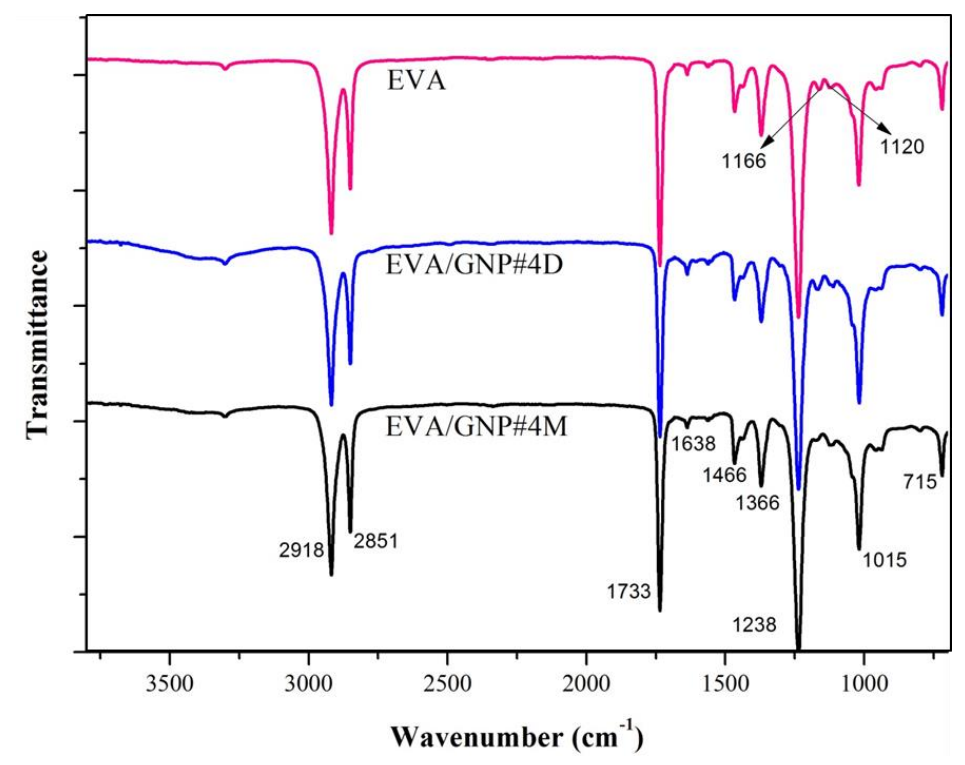

Figure 3. FTIR spectra of the neat EVA and various EVA/GNPs composite films.

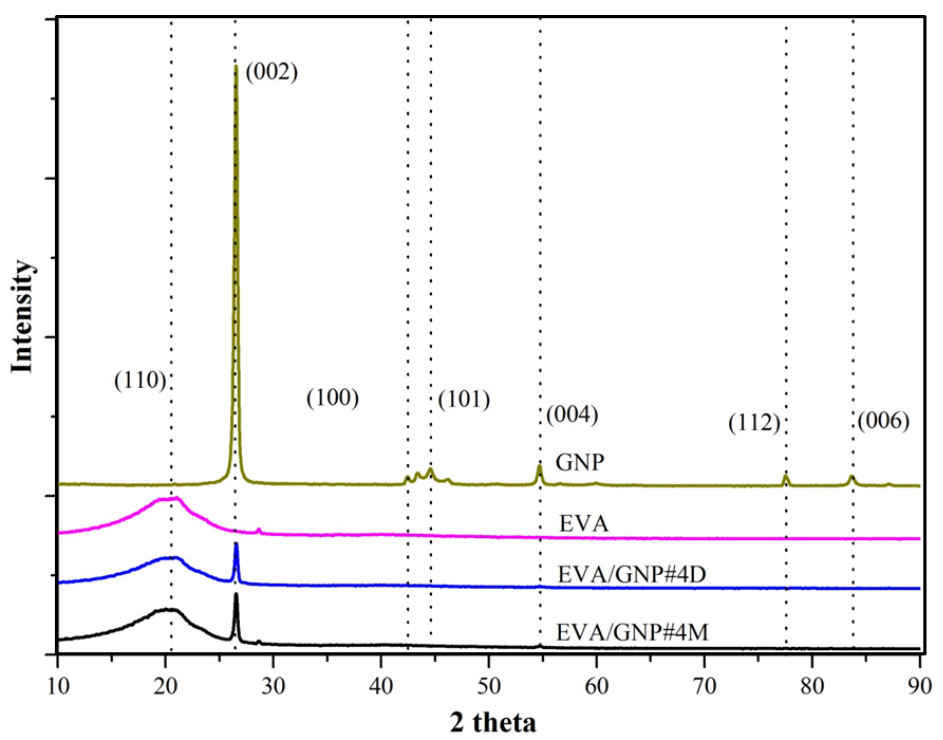

Figure 4. XRD patterns of the neat GNP, EVA and the EVA/GNP composite films. 


\section{Tensile Properties}

The ultimate strength, percentage of elongation and Young's modulus values of the various composite films are summarised in Table 2. In overall, the tensile strength of the neat EVA film increased from 17.05 MPa to the range of 18.29-26.09 MPa, after mixing it with GNP via the direct mixing method. These values are comparable to that of the commercial EVA encapsulant [28], considering the standard deviation values. In addition, the tensile modulus value of the EVA film increased significantly from 6.60 $\mathrm{MPa}$ to the range of 7.52-11.46 MPa, depending on the concentration of GNP. Again, these values are still below $20.7 \mathrm{MPa}$ which was stated in the specifications and requirement of encapsulant for silicon solar cell module [29]. The effects concentration of GNP on tensile properties of the EVA films can be comprehended by consideration of the changes in tensile toughness of the materials as a function of GNP content as shown in Figure 5. The results show that tensile toughness of the EVA based films prepared via the direct mixing changed with the concentration of GNPs in a non-linear fashion. The values initially increased to the maximum point when $0.1 \mathrm{wt} \%$ of the GNP was used, beyond which the values drop again. This was different from that of the composite system prepared via the use of master-batch. In this latter case, tensile modulus and toughness values hardly changed with the concentration of GNP, considering the standard deviation values. The discrepancies might be attributed to several factors, including morphology, crystallinity and crosslinking characteristic of the polymer composites. To clarify these aspects, the results from SEM, DSC/TGA and swelling test described in the following sections should be considered.

Table 2. Tensile properties of the EVA/GNPs composite films.

\begin{tabular}{|c|c|c|c|c|c|}
\hline \multicolumn{3}{|c|}{ Sample Preparation Details } & \multicolumn{3}{|c|}{ Tensile Properties } \\
\hline Sample code & $\begin{array}{l}\text { GNP } \\
(\mathrm{wt} \%)\end{array}$ & Scheme & $\begin{array}{c}\text { Tensile } \\
\text { strength }(\mathrm{MPa})\end{array}$ & $\begin{array}{c}\text { Elongation } \\
(\%)\end{array}$ & $\begin{array}{l}\text { Modulus } \\
(\mathrm{MPa})\end{array}$ \\
\hline The neat EVA & 0 & $\mathrm{n} / \mathrm{a}$ & $17.05( \pm 0.64)$ & $666.35( \pm 7.69)$ & $6.60( \pm 0.58)$ \\
\hline EVA/GNP\#1D & 0.001 & & $19.84( \pm 0.67)$ & $\begin{array}{c}666.46 \\
( \pm 31.40)\end{array}$ & $11.46( \pm 0.62)$ \\
\hline EVA/GNP\#2D & 0.01 & & $20.17( \pm 0.14)$ & $647.80( \pm 7.88)$ & $9.30( \pm 0.47)$ \\
\hline EVA/GNP\#3D & 0.1 & $\begin{array}{l}\text { Direct } \\
\text { Mixing }\end{array}$ & $26.09( \pm 0.60)$ & $\begin{array}{c}640.42 \\
( \pm 49.41)\end{array}$ & $8.25( \pm 0.70)$ \\
\hline EVA/GNP\#4D & 1.0 & & $18.29( \pm 0.69)$ & $\begin{array}{c}562.07 \\
( \pm 35.60)\end{array}$ & $7.52( \pm 0.72)$ \\
\hline EVA/GNP\#1M & 0.001 & & $16.89( \pm 0.55)$ & $\begin{array}{c}756.93 \\
( \pm 50.74)\end{array}$ & $5.69( \pm 0.98)$ \\
\hline EVA/GNP\#2M & 0.01 & Mast & $18.46( \pm 0.86)$ & $\begin{array}{c}659.41 \\
( \pm 10.42)\end{array}$ & $8.75( \pm 1.19)$ \\
\hline EVA/GNP\#3M & 0.1 & Batching & $10.52( \pm 0.85)$ & $\begin{array}{c}850.40 \\
( \pm 76.10)\end{array}$ & $6.20( \pm 0.87)$ \\
\hline EVA/GNP\#4M & 1.0 & & $15.81( \pm 0.47)$ & $\begin{array}{c}631.07 \\
( \pm 14.00)\end{array}$ & $7.22( \pm 1.03)$ \\
\hline Specifications \# & - & $\mathrm{n} / \mathrm{a}$ & $22-25$ & $500-600$ & 6 \\
\hline
\end{tabular}




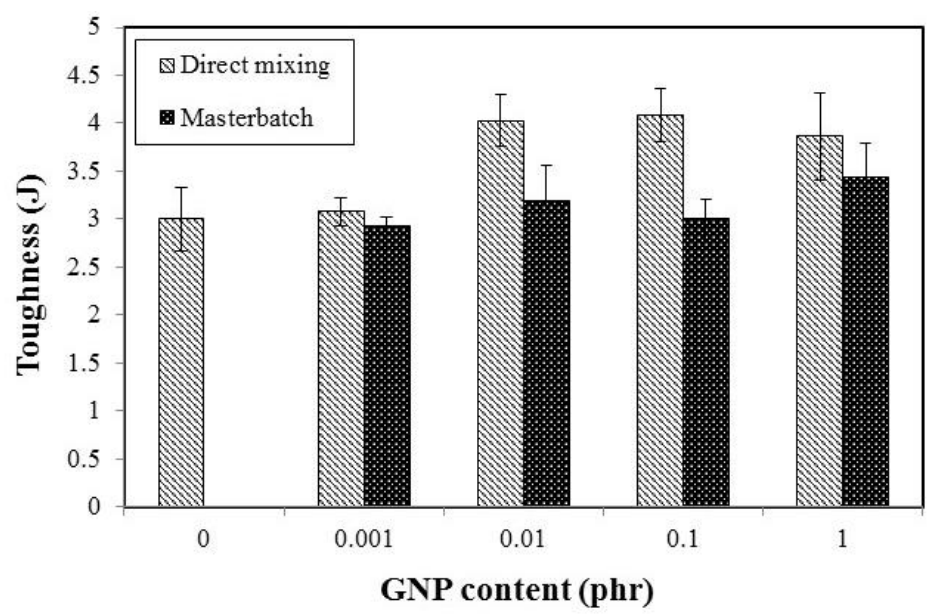

Figure 5. Tensile toughness of EVA composite films with the concentration of graphene nanoplatelets.

\section{Morphology}

Figure 6 shows SEM images of the tensile fractured surface of the composite films, containing $1.0 \mathrm{wt} . \%$ of GNP (referred to the sample code EVA/GNP\#4). Regardless of mixing scheme, an interfacial region between EVA and GNP lacks void or gap. This indicates that the two materials are compatible. This was probably due to the presence of acid functional groups on the structure of the GNP which contribute to the polar-polar interaction. This above factor also contributed to the increase of tensile toughness of the system (Figure 5). It was also observed that GNPs are randomly distributed throughout the EVA matrix phase. Some agglomeration of GNP can also be noted from the enlarged SEM image (see the inset) of the composite film. This feature explains why the tensile toughness of the composite system dropped when the high concentration of GNP was used.

On the other hand, for the system experienced a master-batch mixing scheme, the phase separation became less obvious. Roughness on the surface of the composite specimen is also smoother than that of the direct mixing analogue system. This implies that the extent of rubbery deformation during the tensile testing was lesser in this case. The above observations correspond well to the tensile tested results. In terms of crosslinking characteristics, the results from Table 3 reveal that the gel content value of the EVA/GNP films hardly changed with the concentration of GNP. Overall, the values in the range of $79.7-82.2 \%$ were obtained. These values meet the specification of commercial EVA encapsulant used in industries (80-85\% gel for the standard cure type) [29]. However, the percentage of swelling of the cured EVA film decreased with the concentration of GNP added. In another word, it seems that the crosslinked density of EVA increased with the amount of GNP. The above phenomena were similar to that was observed by Mensah et al. [14] in a study on the effect of graphene oxide (GO) and reduced graphene oxide (rGO) on properties of nitrile rubber (NBR) and ethylenepropylene copolymer (EPDM). In that case, it was found that the addition of $\mathrm{GO} / \mathrm{rGO}$ into the rubbers introduced additional crosslinks. These were ascribed to two main factors, which are, i) the chemical crosslinks between oxygen moieties (carboxylic and hydroxyl groups) on $\mathrm{GO} / \mathrm{rGO}$ and curing ingredient of the rubber compounds and ii) the hydrogen bonding formed between hydroxyl groups on $\mathrm{GO} / \mathrm{rGO}$ and the nitrile groups of NBR. In relation to our present study, however, the EVA was cured by a peroxide curing 
agent and not by the sulfur/accelerator curing system. In this regard, it was possible that additional crosslinks were attributed to a polar-polar interaction between acid groups of the functionalized GNP and acetate groups of the EVA molecules. It was also noteworthy that, when the mixing scheme was changed from the direct mixing to the master batch mixing, the above effect became less pronounced. In our opinion, the above discrepancy could be attributed to the different morphology of the two composite systems.
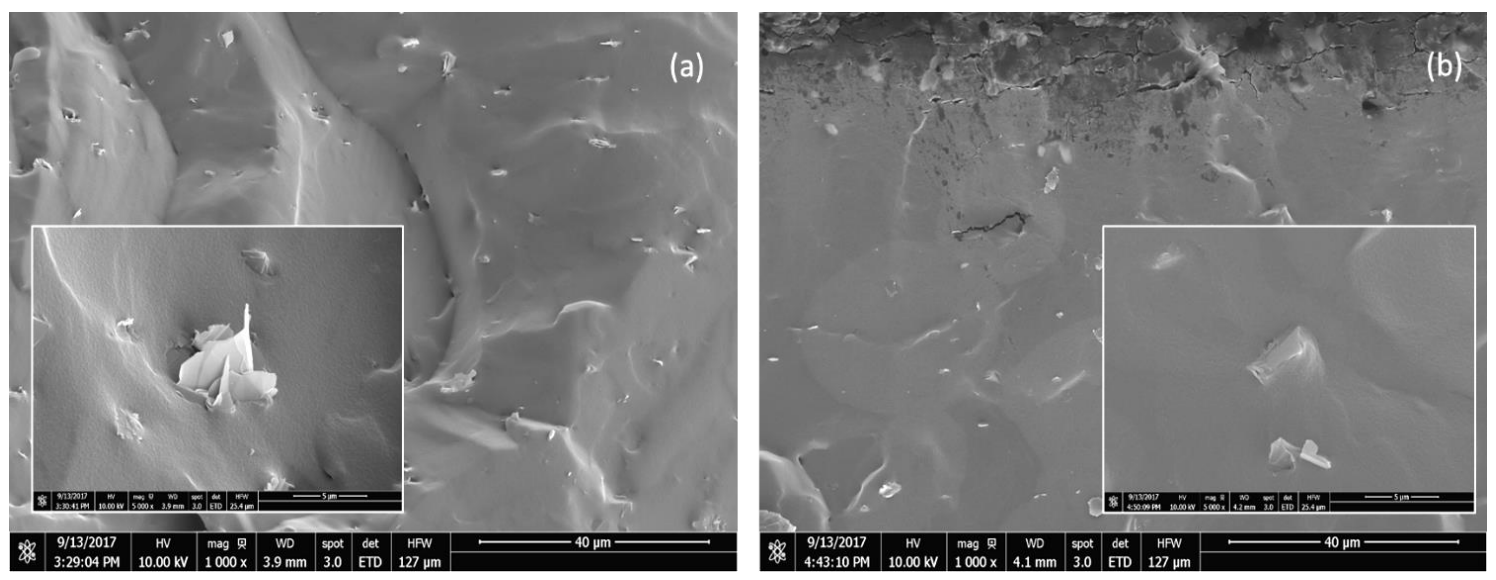

Figure 6. SEM images of composite films from (a) EVA/GNP\#4D specimen experienced direct mixing and; (b) EVA/GNP\#4M specimen mixed via master batch.

Table 3. Physical properties of the EVA/GNPs composite films.

\begin{tabular}{lccccc}
\hline \multicolumn{2}{c}{ Sample Preparation Details } & \multicolumn{3}{c}{ Physical Properties } \\
Sample Codes & $\begin{array}{c}\text { GNP } \\
(\mathrm{wt} \%)\end{array}$ & Scheme & $\begin{array}{c}\text { Gel Content } \\
(\%)\end{array}$ & $\begin{array}{c}\text { Swelling } \\
(\%)\end{array}$ & $\begin{array}{c}\text { Water } \\
\text { Absorption }(\%)\end{array}$ \\
\hline The neat EVA & 0 & n/a & $81.48( \pm 2.46)$ & $1293.9( \pm 37)$ & $0.11( \pm 0.03)$ \\
EVA/GNP\#1D & 0.001 & & $82.24( \pm 1.29)$ & $1074.3( \pm 58)$ & $0.36( \pm 0.05)$ \\
EVA/GNP\#2D & 0.01 & Direct & $80.81( \pm 1.03)$ & $997.1( \pm 44)$ & $0.28( \pm 0.10)$ \\
EVA/GNP\#3D & 0.1 & Mixing & $79.69( \pm 2.75)$ & $768.9( \pm 33)$ & $0.05( \pm 0.04)$ \\
EVA/GNP\#4D & 1.0 & & $81.78( \pm 2.98)$ & $696.1( \pm 59)$ & $0.11( \pm 0.03)$ \\
EVA/GNP\#1M & 0.001 & & $83.87( \pm 2.09)$ & $1370.3( \pm 24)$ & $0.12( \pm 0.09)$ \\
EVA/GNP\#2M & 0.01 & Master & $83.33( \pm 1.60)$ & $1032.1( \pm 30)$ & $0.31( \pm 0.08)$ \\
EVA/GNP\#3M & 0.1 & Batching & $83.15( \pm 2.06)$ & $1032.3( \pm 46)$ & $0.38( \pm 0.06)$ \\
EVA/GNP\#4M & 1.0 & & $83.80( \pm 2.18)$ & $906.1( \pm 49)$ & $0.19( \pm 0.04)$ \\
Specification ${ }^{\#}$ & - & n/a & $80-85$ & n/a & 0.1 \\
\hline
\end{tabular}

\# Refer to the commercial grade (EVAFLEX®) (standard cure type)

\section{Thermal Properties}

Figure 7 shows DSC thermograms of GNP, EVA and the EVA/GNP composite films. An endothermic baseline changes at about $(-33.7){ }^{\circ} \mathrm{C}$ can be observed from the DSC thermogram of the neat EVA film. This corresponds to the glass transition temperature $\left(\mathrm{T}_{\mathrm{g}}\right.$ ) of EVA rubber [30]. In addition, an endothermic peak at about $47.3^{\circ} \mathrm{C}$ can be noted and that represents the melt transition temperature $\left(\mathrm{T}_{\mathrm{m}}\right)$ of the polymer. After compounding with GNP, the $T_{g}$ value of EVA hardly changed whereas the $T_{m}$ value slightly increased at the expense of its enthalpy of melting (Table 4). The percentage of crystallinity of the neat EVA $(10.28 \%)$ slightly dropped to the range of 8.65-9.20\%. after 
mixing with GNP. According to the results in literature, the crystallinity of EVA can be either increased or decreased after mixing with nano-fillers. Sadeghi et al. [31] found that crystallinity of EVA decreased after adding silica while Soheilmoghaddam et al. [17] found that crystallinity of EVA hardly decreased after mixing with GNP. In our opinion, the discrepancies might be attributed to the different mixing method, and the different type and concentration of fillers used.

Figure 8 shows the typical TGA thermograms of GNP, EVA and the EVA/GNP composite films. The neat EVA film exhibits two weight loss transitions at the onset temperatures of $352{ }^{\circ} \mathrm{C}$ (accounted for about $25 \mathrm{wt} \%$ ) and $471{ }^{\circ} \mathrm{C}$ (accounted for about $75 \mathrm{wt} \%$ ). These transitions can be ascribed to the de-acetylation of EVA and the decomposition of polyene intermediates, respectively. The presence of GNP in the composite films did not significantly affect the percentage of weight loss of the EVA. However, after mixing with GNP, EVA became more thermally stable. The onset of a deacetylation temperature of the neat EVA increased from $352^{\circ} \mathrm{C}$ to about $369^{\circ} \mathrm{C}$ and 365 ${ }^{\circ} \mathrm{C}$ after mixing it with GNP via direct mixing and master-batch process, respectively. The similar effect was also observed by Soheilmoghaddam et al. [17]. This was ascribed to the so-called heatsink effect of GNP, which suppressing heat accumulation within the polymer matrix.

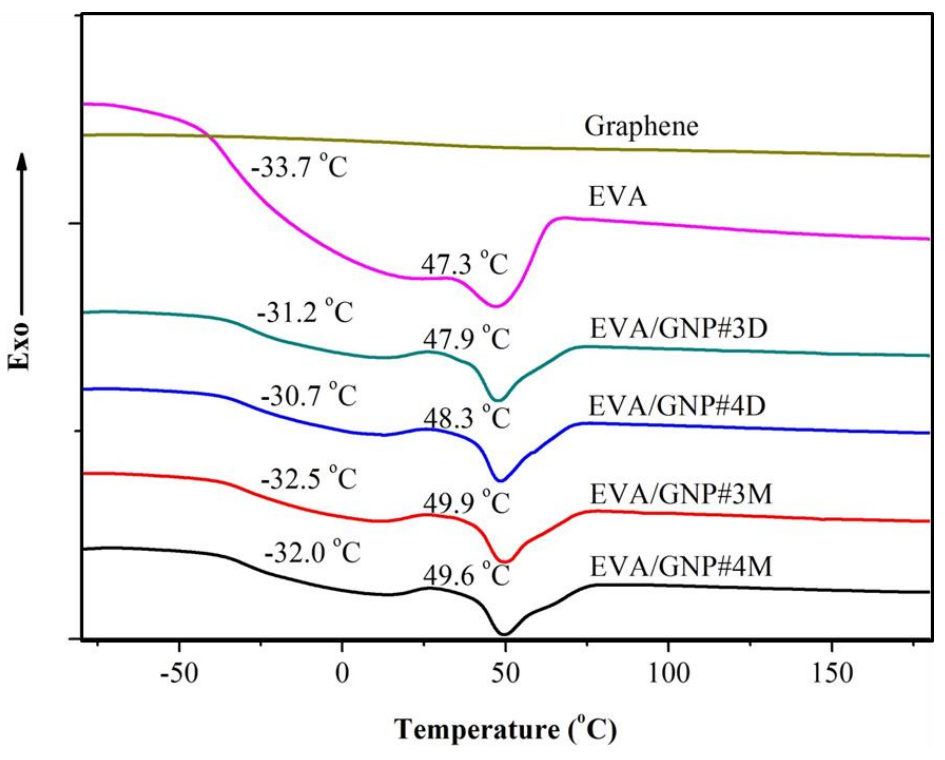

Figure 7. DSC thermograms of GNP and the EVA based films. 


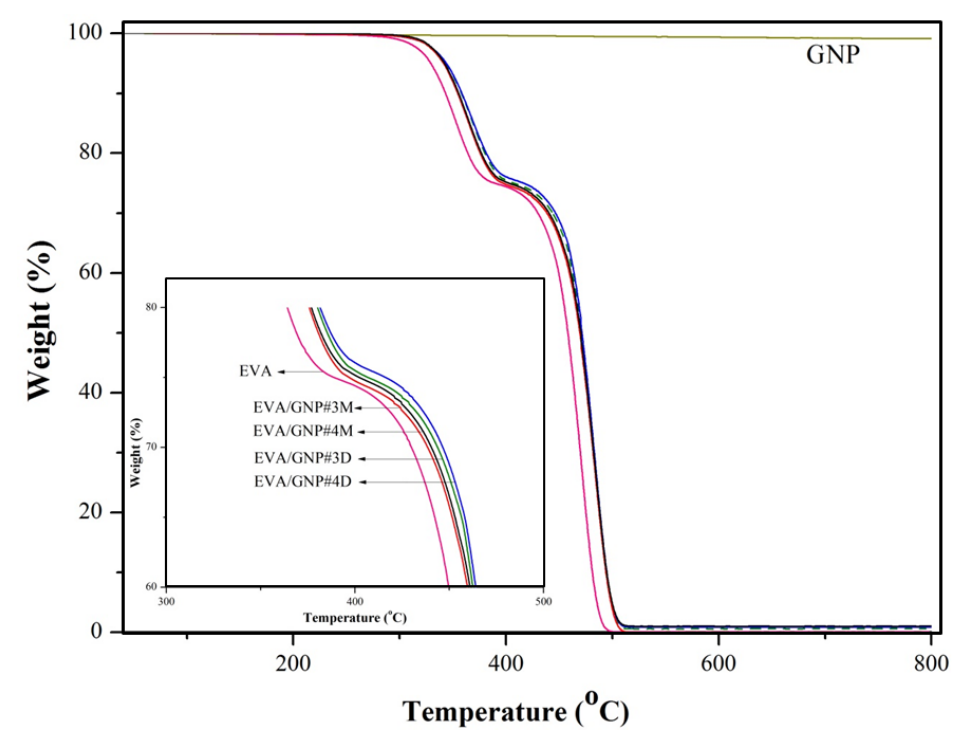

Figure 8. TGA thermograms of GNP and the EVA based films.

Table 4. Transition temperatures, enthalpy of melting, degree of crystallinity $\left(\mathrm{X}_{\mathrm{c}}\right)$, and the onset of decomposition temperatures $\left(\mathrm{T}_{\mathrm{d}}\right)$ of the various EVA/GNP composite films.

\begin{tabular}{lcccccc}
\hline Samples & \multicolumn{4}{c}{ DSC analysis } & \multicolumn{3}{c}{ TGA analysis } \\
Codes & $\mathrm{T}_{\mathrm{g}}\left({ }^{\circ} \mathrm{C}\right)$ & $\mathrm{T}_{\mathrm{m}}\left({ }^{\circ} \mathrm{C}\right)$ & $\Delta \mathrm{H}_{\mathrm{m}}(\mathrm{J} / \mathrm{g})$ & $\mathrm{X}_{\mathrm{c}}(\%)$ & $\mathrm{T}_{\mathrm{d} 1}\left({ }^{\circ} \mathrm{C}\right)$ & $\mathrm{T}_{\mathrm{d} 2}\left({ }^{\circ} \mathrm{C}\right)$ \\
\hline EVA & -33.7 & 47.3 & 30.11 & 10.28 & 351.9 & 470.8 \\
EVA/GNP\#3D & -31.2 & 47.9 & 25.33 & 8.65 & 368.7 & 482.8 \\
EVA/GNP\#4D & -30.7 & 48.3 & 26.95 & 9.20 & 368.2 & 483.6 \\
EVA/GNP\#3M & -32.5 & 49.9 & 25.54 & 8.71 & 364.2 & 483.4 \\
EVA/GNP\#4M & -32.0 & 49.6 & 26.17 & 8.93 & 364.8 & 483.5 \\
\hline
\end{tabular}

\section{Barrier Properties}

The water vapour transmission rates (WVTR) of the various films are illustrated in Figure 9. The measured WVTR value of the neat EVA film is $56.35\left(\mathrm{~g} \mathrm{~m}^{-2} \mathrm{day}^{-1}\right)$. The value is in the same order of magnitude as compared to those that were reported in the literature $[32,33]$. After mixing with GNP, WVTR values of the EVA composite films decreased to the range of 14.54-18.37 $\left(\mathrm{g} \mathrm{m}^{-2} \mathrm{day}^{-1}\right)$, depending on the concentration of GNP used. This effect can be ascribed to the random distribution of GNP throughout the EVA matrix phase (Figure 6), which could induce a tortious pathway for the diffusion of water molecules [5]. The effect of mixing method on WVTR values of the EVA composite films was not significant, taking into account the standard deviation values. Apart from that, it can also be noted that the percentage of water absorption of the EVA composite films were in the range of $0.05-0.38 \%$ (Table 3 ). These values still meet the specification of encapsulating materials to be used with conventional solar cell modules [30] (i.e., water absorption $<0.5$ wt $\%$ at $\left.20{ }^{\circ} \mathrm{C}, 100 \% \mathrm{RH}\right)$. The presence of GNP did not have a significant effect on water absorption of the polymer films, regardless of the concentration of graphene. 


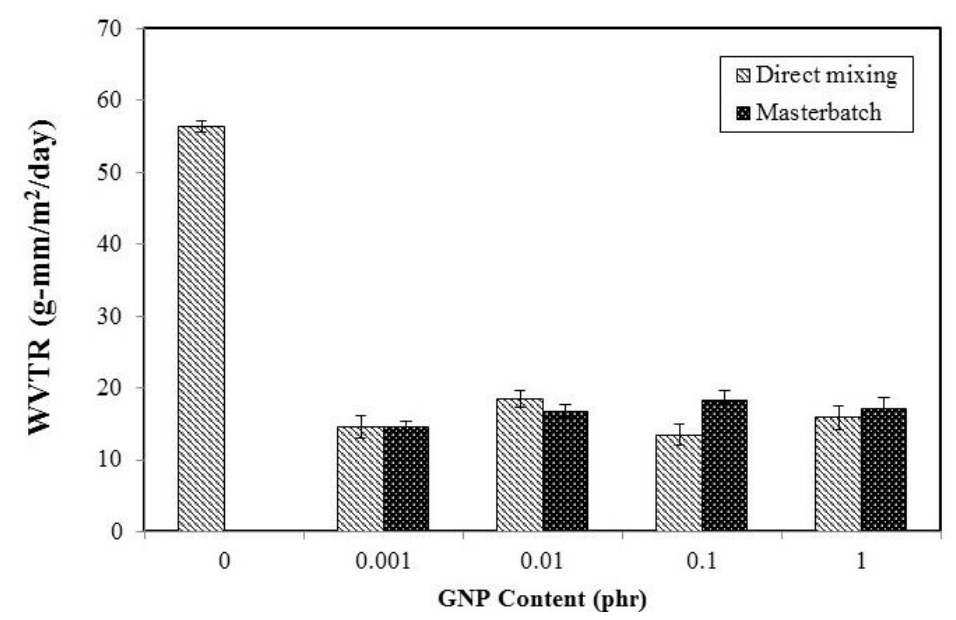

Figure 9. Water vapour transmission rate (WVTR) of the various EVA/GNP composite films.

\section{Optical Properties}

Figure 10 shows the visible light transmittance through the various EVA films. After compounding it with $0.001 \mathrm{wt} \%$ of GNP, the transmittance of the EVA composite film was maintained to the level of about $90 \%$, regardless of the mixing method. This is still higher than the minimum value stated in the specifications and requirement of encapsulant [30]. As the concentration of GNP was further increased to $0.1 \mathrm{wt} \%$, transmittance dropped rapidly to the range of $43-46 \%$. The appearance of the composite films also changed with the concentration of GNP (Figure 11). The composite films with the concentration of GNP in the range of 0.001-0.01 wt \% look more transparent than that containing $0.1 \mathrm{wt} \%$ of GNP. Homogeneity of the composite film prepared via the masterbatch was also poorer than that prepared via the direct mixing method. In this regard, the EVA composite film containing $0.01 \mathrm{wt} \%$ of GNP, prepared by using the direct mixing method (referred to the sample code EVA/GNP\#2D) was selected for use as an encapsulating film for DSSCs.

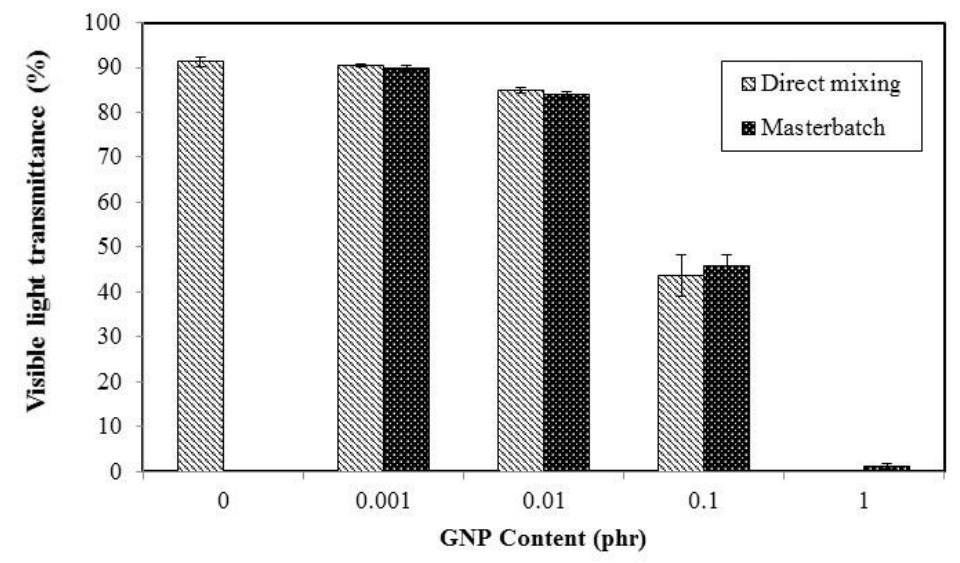

Figure 10. UV/Visible spectra of EVA and EVA/GNP composite films. 

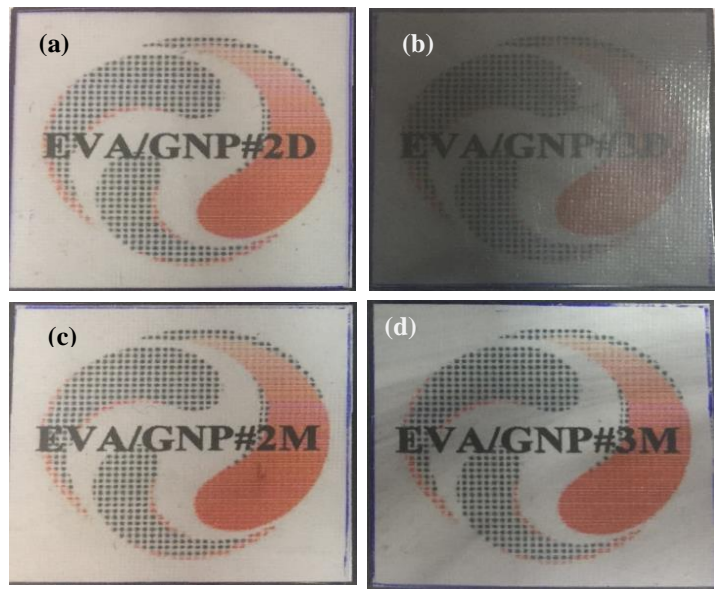

Figure 11. Photographs of the various EVA composite films, (a) EVA/GNP\#2M, (b) EVA/GNP\#3M, (c) EVA/GNP\#2D, (d) EVA/GNP\#3D.

\section{Performance and Lifetime of the DSSCs}

Table 5 shows that the power conversion efficiency (PCE) values of the DSSCs ranged between 3.65-4.45\% were obtained. The materials and process of encapsulation did not significantly affect the performance of the solar cells. Furthermore, Figure 12 shows that the normalised PCE value of the bare DSSC (without any encapsulant) dropped rapidly by more than $50 \%$ within two days. Eventually, after 10 days, the actual power conversion efficiency decreased to below $1.0 \%$. These could be attributed to some leakage and evaporation of the liquid electrolyte within the fabricated cell.

Consequently, the cycle of charge transport between two electrodes and the dye regeneration process were destroyed [34]. On the other hand, by coating the device with PU resin, the lifetime of the device was prolonged by more than three weeks, with the normalized PCE value of 0.74 maintained. By further applying the EVA/GNP composite film on top of the PU coated DSSC, the normalised PCE values of the device dropped at a slower rate. It seems that the use of EVA/GNP as a secondary barrier film can enhance the durability of the PU coated DSSC. This could be attributed to the hydrophobic nature of EVA and the random distribution of GNP within the polymer matrix. It was believed that these factors retard the diffusion of moisture from surrounding into the device as well as inhibit some leakage of liquid electrolyte from the cell.

Table 5. Parameters from the current-voltage (I-V) test of the various DSSC devices.

\begin{tabular}{lccccc}
\hline \multirow{2}{*}{ Devices } & \multicolumn{5}{c}{ Parameters from the I-V test } \\
& $\begin{array}{c}\mathrm{V}_{\mathrm{oc}} \\
(\mathrm{V})\end{array}$ & $\begin{array}{c}\mathrm{I}_{\mathrm{sc}} \\
(\mathrm{mA})\end{array}$ & $\begin{array}{c}\mathrm{J}_{\mathrm{sc}} \\
\left(\mathrm{mA} / \mathrm{cm}^{2}\right)\end{array}$ & $\begin{array}{c}\mathrm{FF} \\
(\%)\end{array}$ & $\begin{array}{c}\text { PCE } \\
(\%)\end{array}$ \\
\hline DSSC (without encapsulation) & 0.642 & 4.12 & 10.31 & 62.56 & 4.14 \\
DSSC encapsulated with PU & 0.688 & 3.15 & 7.87 & 67.50 & 3.65 \\
DSSC encapsulated with PU + EVA & 0.599 & 4.17 & 10.43 & 59.05 & 3.69 \\
DSSC encapsulated with PU + & 0.641 & 4.79 & 11.97 & 57.99 & 4.45 \\
EVA/GNP\#2D & & & & & \\
\hline
\end{tabular}




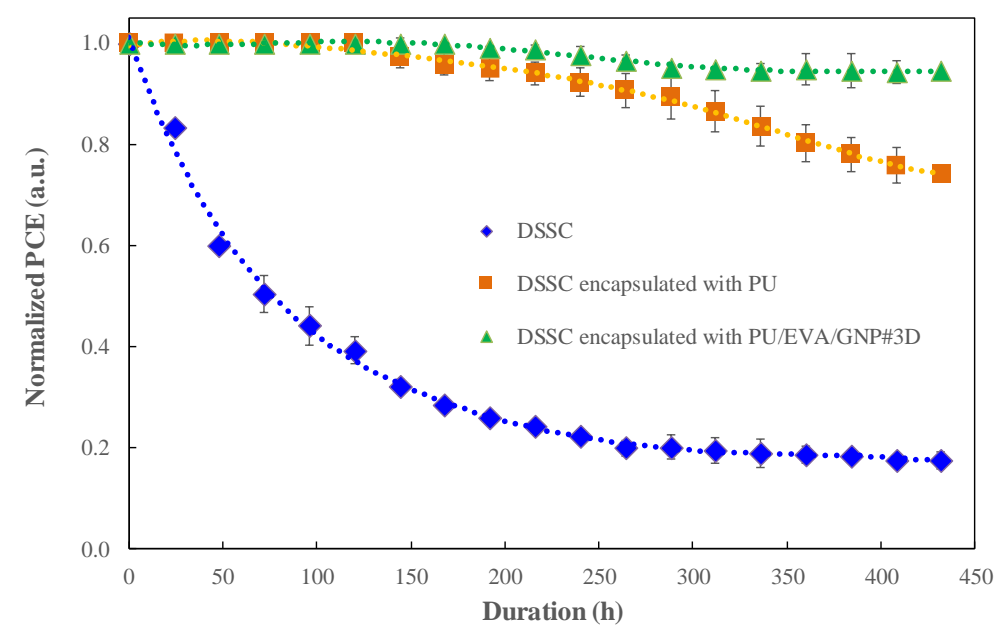

Figure 12. Changes in the normalised PCE values of the various DSSCs as a function of time.

\section{CONCLUSION}

Structure-properties relationships of the transparent barrier films, made by compounding EVA with the acid functionalized graphene nanoplatelets (GNP) via a melt compounding process, were reported. The amount of GNP strongly affected transparency, tensile toughness, and barrier properties of the system. Herein, the optimum concentration of GNP was $0.01 \mathrm{wt}$. \%. This brought about the composite film with the visible light transmittance and water vapour transmission rate in the range of 83.97-85.06\% and 16.77-18.37 ( $\left.\mathrm{g} \mathrm{mm} \mathrm{m}^{2} \mathrm{day}^{-1}\right)$, respectively. The presence of GNP also affects the degree of swelling of the cured EVA film. The higher the concentration of GNP, the lower the swelling index. The above factor contributed to better tensile properties of the polymer. By changing of mixing scheme from the direct mixing method to the master-batch method, the above effects became less pronounced. Last but not least, feasibility of applying the developed composite films for encapsulation of dye-sensitized solar cell (DSSC) was demonstrated. The encapsulated DSSC with a normalized power conversion efficiency of 0.74 and the lifetime of more than three weeks was achieved.

\section{ACKNOWLEDGEMENT}

This work has been supported by the Nanotechnology Center (NANOTEC), NSTDA, Ministry of Science and Technology, Thailand, through its program the Center of Excellence Network. The authors acknowledge the financial support provided by the King Mongkut's University of Technology Thonburi through the "KMUTT 55th Anniversary Commemorative Fund". Special thanks go to Ms Miri Honda from the Division of Environment and Energy, School of Mechanical Engineering, Kanazawa University, Japan, for her contribution in preparing EVA compounds.

\section{REFERENCES}

[1] Zhang H, Ding H, Wei M, Li C, Wei B, Zhang J. Thin film encapsulation for organic light-emitting diodes using inorganic/organic hybrid layers by atomic layer deposition. Nanoscale Research Letters, 2015; 10:169. 
[2] Weerasinghe HC, Dkhissi Y, Scully AD, Caruso RA, Cheng YB. Encapsulation for improving the lifetime of flexible perovskite solar cells. Nano Energy, 2015; 18: 118-125.

[3] Siracusa V. Food Packaging Permeability Behaviour: A Report. International Journal of Polymer Science, Volume, 2012; Article ID 302029: 11 pages

[4] Dennler G, Lungenschmied C, Neugebauer H, Sariciftci NS, Labouret A. Flexible, conjugated polymer-fullerene-based bulk-heterojunction solar cells: Basics, encapsulation, and integration. Journal of Materials Research, 2005; 20: 3224-3233.

[5] Bharadwaj RK, Modeling the barrier properties of polymer-layered silicate nanocomposites. Macromolecules, 2001; 34(26): 9189-9192.

[6] Cho JW, Han JH, Lee GH, Kim KH. Method for manufacturing ethylene vinyl acetate copolymer sheet for solar cell encapsulant, US9034232B2, Granted on 2015-05-19.

[7] Seethamraju S, Ramamurthy P, Madras G. Flexible poly(vinyl alcohol-coethylene)/modified MMT moisture barrier composite for encapsulating organic devices. RSC Advances, 2013; 3: 12831-12838.

[8] Gupta S, Sindhu S, Varman KA, Ramamurthy PC, Madras G. Hybrid nanocopmposies films of polyvinyl alcohol and $\mathrm{ZnO}$ as interactive gas barrier layers for electronic device passivation. RSC Advances, 2012; 2: 11536-11543.

[9] Kopanati GN, Ramamurthy PC, Madras $\mathrm{G} \mathrm{TiO}_{2} / \mathrm{EVOH}$ based reactive interlayer in surlyn for organic device encapsulation. Material Ressearch Express, 2016; 3: 025302.

[10] Yang O, Saito T, Berglund LA, Isogai A. Cellulose nanofibrils improve the properties of all-cellulose composites by the nano-reinforcement mechanism and nanofibril-induced crystallization. Nanoscale, 2015; 7: 17957-17963.

[11] Yu X, Cheng H, Zhang M, Zhao Y, Qu L, Shi G. Graphene-based smart materials. Nature Reviews Materials, 2017; 2: 17046.

[12] Su Y, Kravets VG, Wong SL, Waters J, Geim AK, Nair RR. Impermeable barrier films and protective coatings based on reduced graphene oxide. Nature Communications, 2014; 5:4843.

[13] Tseng IH, Liao YF, Chiang JC, Tsai MH. Transparent polyimide/graphene oxide nanocomposite with improved moisture barrier property. Materials Chemistry and Physics, 2012; 136: 247-253.

[14] Mensah B, Kang SI, Wang W, Nah C. Effect of graphene on polar and non-polar rubber matrix. Mechanics of Advanced Materials and Modern Processes, 2018; 4:1.

[15] Rafiee MA, Rafiee J, Wang Z, Song H, Yu ZZ, Koratkar N. Enhanced mechanical properties of nanocomposites at low graphene content. ACS Nano, 2009; 3(12): 3884-3890.

[16] Gaska K, Xu XD, Gubanski S, Kadar R. Thermal properties of LDPE graphene nanoplatelets composites produced by means of melt extrusion process. Polymers, 2017; 9(1): 11-23.

[17] Soheilmoghaddam M, Adelnia H, Bidsorkhi HC, Sharifzadeh G, Wahit MU, Akos NI, Yussuf AA. Development of ethylene-vinyl acetate composites reinforced with graphene platelets. Macromolecular Materials and Engineering, 2017; 302(2): 1-9.

[18] Yuwawech K, Wootthikanokkhan J, Wanwong S, Tanpichai S. Polyurethane/esterified nanocelluloses composites as a transparent moisture 
barrier coating for encapsulation of dye sensitized solar cells. Journal of Applied Polymer Science, 2017; 134(45): 45010(1-12).

[19] Zou W. A study on mechanical, electrical, and thermal properties of graphene nanoplatelets reinforced epoxy composites. University of Manchester, Master of Philosophy, the Faculty of Science and Engineering, 2016: 22.

[20] HD Plas ${ }^{\mathrm{TM}}$ GNP Technical Data Sheet. Retrieved from https://www.grapheneinfo.com; 18 May, 2018.

[21] Srirodpai O, Wootthikanokkhan J, Nawalertpanya S, Yuwawech K, Meeyoo V. Preparation, characterization and thermo-chromic properties of $\mathrm{EVA} / \mathrm{VO}_{2}$ laminate films for smart window applications and energy efficiency in building. Materials, 2017; 10(53):1-20.

[22] Srirodpai O, Wootthikanokkhan J, Nawalertpanya S. Preparation, Characterizations and Oxidation Stability of Polyethylene Coated Nanocrystalline $\mathrm{VO}_{2}$ Particles and the Thermo-chromic Performance of EVA Composite Films Reinforced with the PE Coated $\mathrm{VO}_{2}$. Journal of Nanoscience and Nanotechnology (in press).

[23] Elanthikkal S, Gopalakrishnapanicker U, Varghese S, Guthrie JT, Francis T. Effect of cellulose whisker content on the properties of poly(ethylene-co-vinyl acetate)/cellulose composites. Carbohydrate Polymers, 2013; 95(2):773-779.

[24] Yuwawech K, Wootthikanokkhan J, Tanpichai S. Transparency, Moisture Barrier Property, and Performance of the Alternative Solar Cell Encapsulants Based on PU/PVDC Blend Reinforced with Different Types of Cellulose Nanocrystal. Materials for Renewable and Sustainable Energy, 2018; 7:21.

[25] Mansur AAP, do Nascimento OL, Mansur HS, Characterization of copolymers poly(ethylene-co-vinyl acetate) and evaluation of their effects in the modified mortars properties. In: Xth World Congress on Ceramic Tile Quality, Castellón, Spain; 10-13 February, 2008.

[26] Dupuy N, Gaston F, Marque SRA, Barbaroux M, Dorey S. FTIR study of ageing of gamma-irradiated biopharmaceutical EVA based film. Polymer Degradation and Stability, 2016; 129: 19-25.

[27] Dai J, Peng C, Wang F, Zhang G, Huang Z. Effects of Functionalized Graphene Nanoplatelets on the Morphology and Properties of Phenolic Resins. Journal of Nanomaterials, 2016; Article ID 3485167: 7 pages.

[28] Isarankura $\mathrm{Na}$ Ayutthaya S, Wootthikanokkhan J. Investigation of the Photodegradation Behaviors of an Ethylene/Vinyl Acetate Copolymer Solar Cell Encapsulant and Effects of Antioxidants on the Photostability of the Material. Journal of Applied Polymer Science, 2008; 107: 3853-3863.

[29] Cazanderna AW, Pern FJ. Encapsulation of PV modules using ethylene vinyl acetate copolymer as a pottant: A critical review. Solar Energy Materials and Solar Cells. 1996; 43: 101-181.

[30] Agroui K, Collins G, Farenc J. Measurement of glass transition temperature of crosslinked EVA encapsulant by thermal analysis for photovoltaic application, Renewable Energy, 2012; 43:218-223.

[31] Sadeghi M, Khanbabaei G, Saeedi Dehaghani AH, Sadeghic M, Aravand MA, Akbarzade M, Khatti S. Gas permeation properties of ethylene vinyl acetatesilicananocomposite membranes. Journal of Membrane Science, 2008; 322(2): 423-428.

[32] Oxygen and Water Vapour Barrier Properties of Flex Pack Films. Retrieved from http://usa.dupontteijinfilms.com; May, 2018. 
[33] Zhu J, Ng C, Montiel-Chicharro D, Betts TR, Gottschalg R. Water vapour transmission rate of Ethylene Vinyl Acetate (EVA):Encapsulant with different curing levels. In: 13th Photovoltaic Science, Application and Technology Conference, Bangor, UK; 5-7 April, 2017.

[34] Hagfeldt A, Gratzel M. Molecular Photovoltaics. Accounts of Chemical Research, 2000; 33: 269-277. 